\title{
Effect of Biscuit Baking Conditions on the Stability of Microencapsulated 5-Methyltetrahydrofolic Acid and Their Physical Properties
}

\author{
Ashok K. Shrestha ${ }^{1,2 *}$, Jayashree Arcot ${ }^{3}$, Sushil Dhital ${ }^{2}$, Sarah Crennan ${ }^{4}$ \\ ${ }^{1}$ School of Science and Health, The University of Western Sydney, Hawkesbury Campus, Richmond, Australia; ${ }^{2}$ Centre for Nutrition \\ and Food Sciences, The University of Queensland, St. Lucia, Brisbane, Australia; ${ }^{3}$ Food Science and Technology, School of Chemi- \\ cal Sciences and Engineering, The University of New South Wales, Sydney, Australia; ${ }^{4}$ Nu-Mega Ingredients Pty Ltd., Brisbane, \\ Australia. \\ Email: *a.shrestha@uws.edu.au
}

Received August $15^{\text {th }}, 2012$; revised September $15^{\text {th }}, 2012$; accepted September $22^{\text {nd }}, 2012$

\begin{abstract}
Among the folate compounds, 5-methyltetrahydrofolic acid $\left(5-\mathrm{CH}_{3} \mathrm{THF}\right)$ is regarded as one of the most bioactive forms of folate. It is regarded as the better source of folate to humans as compared to folic acid, a synthetic form of folate, which is used for fortifying foods to prevent the incidence of neural tube defects in the new born babies. The use of 5- $\mathrm{CH}_{3} \mathrm{THF}$ as an alternative fortificant, in place of folic acid, has been explored by various researchers. However, fortification of $5-\mathrm{CH}_{3} \mathrm{THF}$ is problematic due to its lower stability. This study investigated the stability of microencapsulated 5- $\mathrm{CH}_{3} \mathrm{THF}$ in biscuits baked at various temperatures and times as well as changes in their physical properties. Microcapsule with pectin and alginate ratio of 80:20, prepared by spray drying, gave the highest retention (68.6\%) of the 5- $\mathrm{CH}_{3} \mathrm{THF}$, therefore, chosen for fortification. The encapsulated and unencapsulated 5- $\mathrm{CH}_{3} \mathrm{THF}$ were mixed separately with flour and biscuit ingredients and baked at $180^{\circ} \mathrm{C}, 200^{\circ} \mathrm{C}$ and $220^{\circ} \mathrm{C}$, each for 5,9 and $12 \mathrm{~min}$. The inclusion of encapsulated and unencapsulated 5- $\mathrm{CH}_{3} \mathrm{THF}$ in the biscuit formulation and subsequent baking at various temperatures and times resulted in retention of $5-\mathrm{CH}_{3} \mathrm{THF}$ from $19.1 \%$ to $1.7 \%$. Microencapsulation of $5-\mathrm{CH}_{3} \mathrm{THF}$ slightly improved the retention of $5-\mathrm{CH}_{3} \mathrm{THF}$ over unencapsuated biscuits at $180^{\circ} \mathrm{C}$ for $5 \mathrm{~min}$, but almost no such effect was achieved under baking temperatures of $200^{\circ} \mathrm{C}$ and $220^{\circ} \mathrm{C}$. Physical analysis showed darker colour, harder texture and lower moisture content for biscuits baked at higher test temperatures. It seems intense heating condition that caused "over baking" of the biscuit likely to be responsible for the loss of the vitamin as well as less desirable physical properties of the biscuits.
\end{abstract}

Keywords: 5-Methyltetrahydrofolic Acid; Fortification; Thermal Stability; Microencapsulation; Baking

\section{Introduction}

Folate is one of the most talked about vitamins in recent times due to its potential role in preventing various diseases and disorders such as neural tube defects or NTDs in new born babies, megaloblastic anemia, atherosclerosis, stroke, cancer, Alzheimer's disease, cleft palate, migraine etc. $[1,2]$. This led to widespread folate fortification of foods, particularly in cereal based foods. Folic acid or pteroylglutamic acid (PGA) is the most common form of folate added in foods. It is now mandatory to fortify cereal-based foods in 57 countries. In spite of that, addition of folic acid, a chemically synthesized folate vitamer as a fortificant in foods, is considered less effective or harmful

\footnotetext{
"Corresponding author.
}

to human health as it is potentially linked to increased rate of colorectal and prostate cancer, multiple births etc. [2]. Such controversies have resulted in several countries holding back the mandatory fortification programs.

In Australia, the National Health and Medical Research Council (NHMRC) in the year 1993 recommended a periconceptional daily supplement intake of $0.5 \mathrm{mg}$ folic acid for low risk women and $5 \mathrm{mg}$ for women with a family history of NTDs. This eventually resulted in the voluntary fortification of folic acid in cereal based foods in 1995. In Australia, the overall birth prevalence of NTDs from 1998 to 2005 is reported to be 944 or 4.6 per 10,000 births, remaining more or less unchanged over next 7 years [3]. Prior to 1995 intervention, the total prevalence of NTDs in Australia was reported to be approximately 20 per 10,000 
births. Data from studies (1992-2005) has shown a $26 \%$ decline in NTDs $[3,4]$.

The fact that folic acid might mask the hematological symptoms of vitamin B12 deficiency diseases, while the neurological complications remain in progress, particularly in older populations, is a major concern [5]. The use of 5-methyltetrahydrofolic acid $\left(5-\mathrm{CH}_{3} \mathrm{THF}\right)$ which cannot possibly mask the Vitamin B12 deficiency is now considered as an alternative to folic acid [6]. Besides 5$\mathrm{CH}_{3} \mathrm{THF}$ is more natural form of folate and have similar bioavailability as folic acid [7]. Historically, 5- $\mathrm{CH}_{3} \mathrm{THF}$ has not been considered as a good folate fortificant as it is expensive to synthesize and is less stable as compared to folic acid. But the cost is likely to go down if it is massproduced. As stated in the Food Standard Australia and New Zealand (FSANZ) report on folic acid fortification, these costs are likely to be minimal on the basis of the following: new market opportunities may arise through the use of 5- $\mathrm{CH}_{3} \mathrm{THF}$; industry will have the choice to use either $5-\mathrm{CH}_{3} \mathrm{THF}$ or folic acid as appropriate for their products; labeling costs may be absorbed through normal business cycles. There may also be a direct benefit to some consumers through consuming a form of folate that is considered unlikely to mask symptoms of a Vitamin B12 deficiency. It is reported to be about 4 times more expensive than PGA [8]. It may remain more expensive than PGA but the production cost will go down if it is mass-produced.

Folate compounds, 5- $\mathrm{CH}_{3} \mathrm{THF}$ in particular, are reported to be susceptible to thermal degradation, high hydrostatic pressure, presence of various levels of oxygen, extreme $\mathrm{pH}$, presence of various chemicals etc. [9]. Existing literatures indicate that $5-\mathrm{CH}_{3} \mathrm{THF}$ cannot be directly used as a fortificant in foods as it is most likely to undergo oxidation during processing. Our recent paper has shown that microencapsulation as one of the methods that potentially improve the stability of $5-\mathrm{CH}_{3} \mathrm{THF}$ in cereal based foods [9].

Biscuits or cookies are widely consumed snacks, therefore, along with bread and other-cereal based foods, is an ideal food for folate fortification. There have been few studies where the effect of bread baking on folate compounds is studied but there is no data on stability of 5$\mathrm{CH}_{3} \mathrm{THF}$ vitamer in biscuit [10-12]. This project is aimed at investigating the delivery of encapsulated and unencapsulated 5- $\mathrm{CH}_{3} \mathrm{THF}$ into the biscuit and the recovery of 5- $\mathrm{CH}_{3} \mathrm{THF}$ under different baking times and temperatures. Besides, the effects of these baking conditions on the quality parameters of biscuits such as texture, moisture, and colour of the biscuits are also investigated. So far, there is no study on microencapsulation of 5- $\mathrm{CH}_{3} \mathrm{THF}$ and its stability during biscuit baking.

\section{Materials and Methods}

\subsection{Materials}

The vitamin $5-\mathrm{CH}_{3} \mathrm{THF}$ [(6R,S)-5-Methyl-5,6,7,8 tetrahydrofolic acid calcium salt] was purchased from Schricks Laboratories, Jona, Switzerland. All the ingredients required for biscuits preparation such as, plain soft wheat flour, vegetable oil, sugar, baking soda, vanilla, common salt and lecithin were purchased from the local supermarket (Table 1). One g of encapsulated 5- $\mathrm{CH}_{3} \mathrm{THF}$ $(1801 \mu \mathrm{g})$ was used in one formulation whereas $2375 \mu \mathrm{g}$ unencapsulated or free $5-\mathrm{CH}_{3} \mathrm{THF}$ powder was used in the other formulation. Distilled de-ionized water was used throughout the analysis.

\subsection{Microencapsulation of $5-\mathrm{CH}_{3} \mathrm{THF}$}

5- $\mathrm{CH}_{3} \mathrm{THF}$ was encapsulated in a combination of pectin (P) and sodium alginate (A) [(P60:A40), (P70:A30) and P80:A20)] using spray drying. Details of the microencapsulation procedure are given in our previous paper [9]. The loading efficiency of the spray dried $5-\mathrm{CH}_{3} \mathrm{THF}$ microcapsule was studied following the protocol described by Madziva i.e., release of microencapsulated 5$\mathrm{CH}_{3}$ THF in $0.1 \mathrm{M}$ phosphate buffer at $\mathrm{pH} 8.2$ [13].

\subsection{Preparation of $5-\mathrm{CH}_{3} \mathrm{THF}$ Fortified Biscuits}

Plain flour and encapsulated $5-\mathrm{CH}_{3} \mathrm{THF}$ ( $1 \%$ of total solids) or unencapsulated 5- $\mathrm{CH}_{3} \mathrm{THF}$ were mixed using a Hobart Planetary Mixer A200 (Hobart, Australia) in a

Table 1. Formulation of biscuit ingredients with encapsulated and unencapsulated $5-\mathrm{CH}_{3} \mathrm{THF}$.

\begin{tabular}{ccc}
\hline \multirow{2}{*}{ Ingredients } & \multicolumn{2}{c}{ Quantity, g (\%) } \\
\cline { 2 - 3 } & $\begin{array}{c}\text { Encapsulate } \\
5-\mathrm{CH}_{3} T H F, \mathrm{~g}(\%)^{1}\end{array}$ & $\begin{array}{c}\text { Unencapsulate } \\
5-\mathrm{CH}_{3} T H F, \mathrm{~g}(\%)\end{array}$ \\
\hline Plain flour & $234.0(55.4)$ & $235.9(55.9)$ \\
Vegetable oil & $84.0(19.9)$ & $84.8(20.1)$ \\
Sugar & $70.1(16.6)$ & $70.9(16.8)$ \\
Water & $23.2(5.5)$ & $23.6(5.6)$ \\
Baking soda & $2.8(0.7)$ & $2.8(0.7)$ \\
Vanilla & $1.9(0.4)$ & $1.7(0.4)$ \\
Common salt & $1.9(0.4)$ & $1.7(0.4)$ \\
Lecithin & $0.3(0.1)$ & $0.3(0.1)$ \\
5-CH $\mathrm{CHF}$ & $4.20(1.0)$ & $2375 \mu \mathrm{g}$ \\
microcapsule & & $422(100)$ \\
Total & $422.3(100)$ &
\end{tabular}

${ }^{1} 429 \mu \mathrm{g}$ of $5-\mathrm{CH}_{3} \mathrm{THF} / \mathrm{g}$ microcapsule or $1801 \mu \mathrm{g} / 422.3 \mathrm{~g}$ fortified biscuit. 
dark room for 10 minutes and placed into the aluminum laminated foil bags. The experiment was performed entirety in a single day to reduced variation between batches. All the ingredients were weighed individually into separate containers. Water, sugar, salt and vanilla were added together as given in the Table 1 and stirred until dissolve in solution. Oil and lecithin were then added and agitated using a Kenwood Major KM201 (Kenwood; UK) for 5 minutes. Flour and bicarbonate soda were added and mixed for a further 3 minutes. The dough was then split into $20 \mathrm{~g}$ portions and shaped using a cookie cutter, diameter $4.5 \mathrm{~cm}$, thickness $5 \mathrm{~mm}$. Biscuits containing either unencapsulated $5-\mathrm{CH}_{3} \mathrm{THF}$ or encapsulated $5-\mathrm{CH}_{3} \mathrm{THF}$ were baked in a pre-heated Convotherm Convostar oven (APV Moffat; Germany) at three temperatures; $180^{\circ} \mathrm{C}$, $200^{\circ} \mathrm{C}$ and $220^{\circ} \mathrm{C}$ for three different lengths of time of 5, 9 and 12 minutes, until the biscuit become hard and golden brown. These baking temperatures were selected based on the previous baking studies by Jisha et al. and with some trials in the current oven [14]. Three batches of biscuits were prepared, one batch had 18 biscuits under 3 different temperatures and times (replicates 1, 2 and 3) (Table 2). These biscuits were cooled and placed into sealable aluminum foil bags and later used for analysis of physical properties (refrigerate, $4^{\circ} \mathrm{C}$ ) and $5-\mathrm{CH}_{3} \mathrm{THF}$ content (kept frozen, $-18^{\circ} \mathrm{C}$ ). To distinguish the effect of encapsulation and baking temperature at various baking times, analysis of variance (ANOVA) and multiple range tests were conducted on the sample means [15].

\subsection{Measurement of Physical Properties}

Moisture content of the biscuits was measured by vacuum oven method [16]. All the biscuits were cryo-milled in the liquid nitrogen bath (6850 Freezer/Mill, SPEX CertiPrep Inc., Metuchen, New Jersey, USA) and transferred into dark bottles and kept at $-18^{\circ} \mathrm{C}$ for subsequent $5-\mathrm{CH}_{3} \mathrm{THF}$ extraction. Cryo-milling was used to ensure no heat damage of the vitamin occurs due to heat produced during conventional grinding of biscuit. Moisture content of freeze-dried biscuits was close to zero. Color characteristics (" $L "$ ", " $a$ " and " $b$ ") of biscuits were measured by Chroma Meter CR-400/410 (Konica Minolta Sensing Inc., Tokyo, Japan). The Chroma Meter was calibrated against a white standard plate before actual color measurement. In this system, $L$ value indicates lightness, $+a$ value indicates "redness" and $-a$ to greenness, $+b$ value indicates yellowness and $-b$ to blueness. Five replicate measurements were performed for each sample. Biscuits were compared for their relative colour difference $\left(\Delta E_{a b}^{*}\right)$ from the control

Table 2. Randomized experimental design of biscuit experiments ${ }^{1}$.

\begin{tabular}{|c|c|c|c|c|c|}
\hline Replication & Order & $5-\mathrm{CH}_{3} \mathrm{THF}$ sources & Temperature $\left({ }^{\circ} \mathrm{C}\right)$ & Time (min) & Sample codes \\
\hline \multirow[t]{18}{*}{ Replicate1 } & 1 & Encapsulated & 220 & 12 & R1 1 \\
\hline & 2 & Encapsulated & 220 & 9 & R1 2 \\
\hline & 3 & Encapsulated & 220 & 5 & R1 3 \\
\hline & 4 & Unencapsulated & 220 & 9 & R1 4 \\
\hline & 5 & Unencapsulated & 220 & 5 & R1 5 \\
\hline & 6 & Unencapsulated & 220 & 12 & R1 6 \\
\hline & 7 & Encapsulated & 180 & 9 & R1 7 \\
\hline & 8 & Encapsulated & 180 & 5 & R1 8 \\
\hline & 9 & Encapsulated & 180 & 12 & R1 9 \\
\hline & 10 & Unencapsulated & 180 & 5 & R1 10 \\
\hline & 11 & Unencapsulated & 180 & 9 & R1 11 \\
\hline & 12 & Unencapsulated & 180 & 12 & R1 12 \\
\hline & 13 & Unencapsulated & 200 & 5 & R1 13 \\
\hline & 14 & Unencapsulated & 200 & 9 & R1 14 \\
\hline & 15 & Unencapsulated & 200 & 12 & R1 15 \\
\hline & 16 & Encapsulated & 200 & 9 & R1 16 \\
\hline & 17 & Encapsulated & 200 & 5 & R1 17 \\
\hline & 18 & Encapsulated & 200 & 12 & R1 18 \\
\hline
\end{tabular}

${ }^{1}$ Only replicate 1 is displayed in the current table and replicates 2 (R2) and 3 (R3) not displayed. 
colour white $\left(L^{*}=97.146, a^{*}=5.2048, b^{*}=-3.453\right)$. Colour difference was determined by the following formulation:

$$
\Delta E_{a b}^{*}=\sqrt{\left(\Delta L^{*}\right)^{2}+\left(\Delta a^{*}\right)^{2}+\left(\Delta b^{*}\right)^{2}}
$$

The texture of the biscuits was measured using a stable micro system TA.XT Plus Texture Analyser (Arrow Scientific Pty Ltd. Lane Cove N.S.W, Australia) with a $\mathrm{HDP} / 3 \mathrm{~PB}$ three-point bend rig attachment. The maximum force $(\mathrm{N})$ required to break the biscuit was measured, and the resulting graphs were recorded. The biscuits were at room temperature and of uniform size. The TA.XT Plus machine was calibrated to a set load $(5 \mathrm{~kg})$ and height. For each texture and colour different analysis, six (biscuits) replicates were used.

\subsection{Analysis of $5-\mathrm{CH}_{3} \mathrm{THF}$ from Foods}

The 5- $\mathrm{CH}_{3} \mathrm{THF}$ from the ground sample was extracted by simple boiling and centrifugation as described previously [17]. Further extraction of $5-\mathrm{CH}_{3} \mathrm{THF}$, filtration, purification by solid phase extraction, standard and sample preparation for HPLC analysis and quality control were followed by the method as previously described [9].

\section{Results and Discussion}

\subsection{Sample Analysis and HPLC Performance}

HPLC analysis of standards showed folic acid and 5$\mathrm{CH}_{3} \mathrm{THF}$ were well separated by the current protocol of gradient elution in the given column. The retention time for 5- $\mathrm{CH}_{3} \mathrm{THF}$ was $16.76 \mathrm{~min}$ (Figure 1). Folic acid was analysed along with $5-\mathrm{CH}_{3} \mathrm{THF}$ had retention time of $20.41 \mathrm{~min}$. It was also noted that the retention times of both folate compounds changed slightly between injections. However, it did not affect the absolute value of the folate compounds in the samples. These slight variations could be due to differences in concentration of mobile phase, elution buffer, column temperature and other factors that possibly influence the mobility of the analytes in the column. Some minor peaks also appeared in the vicinity of the folic acid and 5- $\mathrm{CH}_{3} \mathrm{THF}$ peaks indicating possible breakdown of these compounds.

The processed samples were extracted in the buffer containing combined antioxidants, 2-mercaptoethanol and ascorbate to prevent folic acid loss during the extraction and analysis [18]. The chromatograms of sample extracts showed the solid phase extraction (SPE) technique ensured separation of 5- $\mathrm{CH}_{3} \mathrm{THF}$ and subsequent detection of folate compounds by HPLC (Figure 1). Recovery of 5- $\mathrm{CH}_{3} \mathrm{THF}$ during solid phase extraction (SPE-SAX) was also tested that showed the recovery of the vitamin at close to $85 \%-112 \%$. It is deemed to be satisfactory as majority of the vitamin being permeated through the column.

\subsection{Loading Efficiency 5- $\mathrm{CH}_{3} \mathrm{THF}$ Microcapsule}

Spray drying was chosen as the method of encapsulation due to its availability, cost effectiveness and widespread use in food industries. Details of loading efficiency of 5- $\mathrm{CH}_{3} \mathrm{THF}$ in the spray dried microcapsule or encapsulate is already described in the previous paper [9]. Results showed loading efficiency of 5- $\mathrm{CH}_{3} \mathrm{THF}$ in microcapsule at pectin:alginate ratios of (P80:A20), (P70:A30) (P60: A40) resulting in recovery of $68.6 \%, 46.9 \%$ and $26.1 \%$ with the $5-\mathrm{CH}_{3} \mathrm{THF}$ content ranging from 429, 293 and $163 \mu \mathrm{g} / \mathrm{g}$, respectively. Previous data also showed pectin

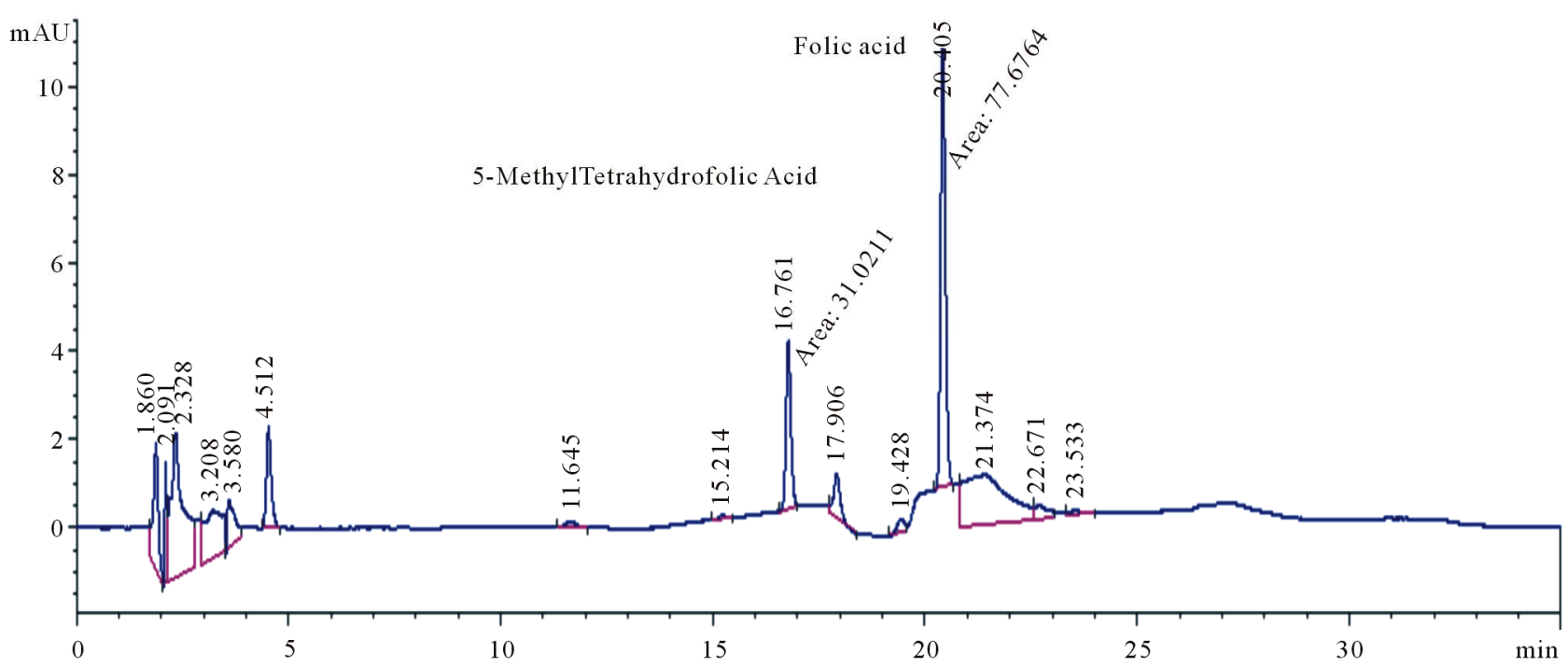

Figure 1. Chromatogram of standard mixtures of folic acid and $5-\mathrm{CH}_{3} \mathrm{THF}$ at $200 \mathrm{ng} / \mathrm{mL}$. 
improves the gel strength, mixture stability, barrier property to water and gives homogeneity, uniformity of pore size and strength when used along with alginate [19-21].

\subsection{Fortification of Biscuits with $5-\mathrm{CH}_{3} \mathrm{THF}$}

As previously mentioned, microcapsule with the highest recovery or $429 \mu \mathrm{g} 5-\mathrm{CH}_{3} \mathrm{THF} / \mathrm{g}$ capsule was used in biscuit formulation (426 $\mu \mathrm{g} / \mathrm{g}$ fortified biscuit) whereas $563 \mu \mathrm{g} 5-\mathrm{CH}_{3} \mathrm{THF} / \mathrm{g}$ was added to per g unencapsulated fortified biscuit formulation (Table 1). Relatively higher amount of 5- $\mathrm{CH}_{3} \mathrm{THF}$ was added to unencapsulated fortified biscuit as it is more likely to degrade than the one from the encapsulated fortified biscuit. Table 3 shows that the baking temperatures and times largely affected the retention of added 5- $\mathrm{CH}_{3} \mathrm{THF}$, in both encapsulated and unencapsulated fortified biscuits. Fortified biscuit with encapsulated $5-\mathrm{CH}_{3} \mathrm{THF}$ heated at $180^{\circ} \mathrm{C}$ for $5 \mathrm{~min}$ showed the highest retention of $5-\mathrm{CH}_{3}$ THF (19.1\%) but further heating significantly $\left(\mathrm{p} \geq 0.05\right.$ ) reduced $5-\mathrm{CH}_{3} \mathrm{THF}$ to $8.5 \%$ at $200^{\circ} \mathrm{C}$ and $4.9 \%$ at $220^{\circ} \mathrm{C}$. This study clearly showed very low retention of $5-\mathrm{CH}_{3} \mathrm{THF}$ at elevated temperatures particularly at or above $200^{\circ} \mathrm{C}$. Baking of 5$\mathrm{CH}_{3} \mathrm{THF}$ encapsulated biscuits from $200^{\circ} \mathrm{C}$ to $220^{\circ} \mathrm{C}$ at 5 to $12 \mathrm{~min}$ resulted in further reduction, with retention of vitamin ranging from $5.1 \%$ to $6.8 \%$. The loss of vitamin appeared to be indiscriminate of processing conditions, e.g., time and temperature.

Fortified biscuits with unencapsulated 5- $\mathrm{CH}_{3} \mathrm{THF}$ had severe destruction of $5-\mathrm{CH}_{3} \mathrm{THF}$ (Table 3). The highest and lowest retention of unencapsulated $5-\mathrm{CH}_{3} \mathrm{THF}$ were $6.7 \%$ and $1.7 \%$ for biscuits baked for 5 and $12 \mathrm{~min}$ at $200^{\circ} \mathrm{C}$, respectively, following indiscriminate trend of 5$\mathrm{CH}_{3} \mathrm{THF}$ loss as shown in the encapsulated samples.

Considering a half-life period of $21.4 \mathrm{~min}$ at $100^{\circ} \mathrm{C}$, loss of $5-\mathrm{CH}_{3} \mathrm{THF}$ during baking (temperature $>180^{\circ} \mathrm{C}$ ) was anticipated [22]. It was also expected that microencapsulation would give a certain degree of protection to the vitamin during heat processing but the outcome was not encouraging. Our previous study showed that the use of encapsulated 5- $\mathrm{CH}_{3} \mathrm{THF}$ gives better retention in the extrudates (temperature ranging from $100^{\circ} \mathrm{C}-150^{\circ} \mathrm{C}$ ) as compared to unencapsulated. The vitamin degradation was much less in the extrudates containing encapsulated 5- $\mathrm{CH}_{3} \mathrm{THF}$ as compared to unencapsulated, particularly at higher temperatures, from $120^{\circ} \mathrm{C}$ and $150^{\circ} \mathrm{C}$ [9]. It appears that baking causes higher degradation of 5- $\mathrm{CH}_{3} \mathrm{THF}$ than extrusion, in both encapsulated and unencapsulated vitamin containing biscuits. Higher processing temperature and larger exposed surface area to volume that facilitate oxidation of 5- $\mathrm{CH}_{3} \mathrm{THF}$ could be few factors contributing towards such a heavy loss of the vitamin.

There are very few published literatures on the effect of processing on added 5- $\mathrm{CH}_{3} \mathrm{THF}$ in cereal-based foods. Crystalline L-5- $\mathrm{CH}_{3} \mathrm{THF}-\mathrm{Ca}$ tablet is reported to be stable during long-term storage ( 48 months at $40^{\circ} \mathrm{C}$ and up to $75 \% \mathrm{RH}$ ) [23]. Ohrvik et al. recently reported the retention of Ca salt of [6S]-5- $\mathrm{CH}_{3}$ THF during bread baking at about $220^{\circ} \mathrm{C}$ (inner temperature for $96^{\circ} \mathrm{C}$ ) for more than $90 \mathrm{~min}$, total baking and cooling time about $5 \mathrm{~h}$, ranged from $31 \%$ to $38 \%$ [24]. Study also showed more endogenous $5-\mathrm{CH}_{3} \mathrm{THF}$ was retained (75\%) compared to the externally added folate vitamer.

Baking methods for cakes, breads and biscuit are different. In bread, baking temperature is lower over a longer period of time and the moisture gradient is at atmospheric conditions so the moisture escapes at an even rate before a crust forms. As a result of this, the inside temperature of the food does not exceed $100^{\circ} \mathrm{C}$. However, in the current study, baking a thin $(5 \mathrm{~mm})$ biscuit dough with relatively low moisture content $(\sim 20 \%)$ means moisture from the surface evaporates rapidly and there is little gradient of moisture and temperature. Heat transfer by a combination of conduction, convection and radiation are likely to establish the biscuit temperature closer to the baking temperature. It was noticed that baking at a higher temperature, from $200^{\circ} \mathrm{C}$ onwards resulted in surface charring of

Table 3. Measurement 5- $\mathrm{CH}_{3} \mathrm{THF}$ of biscuits baked at different temperatures and times.

\begin{tabular}{|c|c|c|c|c|}
\hline \multirow{2}{*}{ Physical properties } & \multirow{2}{*}{ Baking temperature $\left({ }^{\circ} \mathrm{C}\right)$} & \multicolumn{3}{|c|}{ Baking time $(\min )^{1,2}$} \\
\hline & & 5 & 9 & 12 \\
\hline \multirow{3}{*}{ Encapsulated } & 180 & $19.1 \pm 3.0 \mathrm{~b}$ & $5.3 \pm 0.6 \mathrm{a}$ & $5.0 \pm 1.9 \mathrm{a}$ \\
\hline & 200 & $8.5 \pm 1.1 \mathrm{a}$ & $5.1 \pm 0.8 \mathrm{a}$ & $6.4 \pm 1.4 \mathrm{a}$ \\
\hline & 220 & $4.9 \pm 0.5 \mathrm{a}$ & $6.8 \pm 1.2 \mathrm{a}$ & $6.3 \pm 1.8 \mathrm{a}$ \\
\hline \multirow{3}{*}{ Unencapsulated } & 180 & $5.4 \pm 0.4 \mathrm{a}$ & $5.4 \pm 0.6 \mathrm{a}$ & $2.9 \pm 0.7 \mathrm{a}$ \\
\hline & 200 & $6.7 \pm 1.0 \mathrm{a}$ & $5.1 \pm 0.8 \mathrm{a}$ & $1.7 \pm 0.4 \mathrm{a}$ \\
\hline & 220 & $4.4 \pm 0.6 \mathrm{a}$ & $6.5 \pm 1.2 \mathrm{a}$ & $4.2 \pm 1.0 \mathrm{a}$ \\
\hline
\end{tabular}

${ }^{1}$ Significance of LSD test of treatment means at $\mathrm{p} \leq 0.05$ and standard deviation (of triplicates); ${ }^{2}$ Means with the same superscript within the same column are not significantly different. 
the biscuits (picture not shown). Therefore, heat sensitive vitamins are more likely to be destroyed during biscuit baking compared to bread baking.

Previous studies have also reported a loss of $7 \%$ to $67 \%$ endogenous $5-\mathrm{CH}_{3} \mathrm{THF}$ when proofed dough is baked at about $240^{\circ} \mathrm{C}$ for $40 \mathrm{~min}[10,12]$. Biodar has referred to their unpublished data that reported the micro-encapsulated $5-\mathrm{CH}_{3} \mathrm{THF}-\mathrm{Ca}$ (using inert carriers) is about $90 \%$ recoverable from baked bread, and $75 \%$ recoverable from breakfast cereals, in which it had been incorporated during the manufacturing process [25]. Biodar further reported the 5- $\mathrm{CH}_{3} \mathrm{THF}$-Ca could be released completely from the encapsulation by incubation in an artificial digestive system at $\mathrm{pH} 6.8$ for 3 hours. It has also been suggested that $5-\mathrm{CH}_{3} \mathrm{THF}-\mathrm{Ca}$ in microencapsulated form, preferably with ascorbate as an antioxidant, has long-term stability in a variety of foodstuffs [23]. A recent study by Tomiuk et al. (2012) reported the use of skim milk powder as the encapsulating agent for $5-\mathrm{CH}_{3} \mathrm{THF}$ using spray drying and subsequent fortification in bread. The recovery of microencapsulated $5-\mathrm{CH}_{3} \mathrm{THF}$ from the bread was $81 \%$, which further increased to $87 \%$ when ascorbic acid was incorporated into the formulation.

\subsection{Change in Colour Parameters}

Biscuit baked at $180^{\circ} \mathrm{C}$ appeared to be golden brown in color which is the characteristic of baked cereal foods. High temperature and low moisture content in the surface layers cause caramelization of sugars and oxidation of fatty acids to aldehydes, lactones, ketones, alcohols and esters which cause a deeper brown colour [26]. Color development in sugar and protein rich system like bis- cuits, which is baked at higher temperature, is caused by Maillard reaction. The golden brown color in biscuits turned to intense red and dark when baked for short times at $200^{\circ} \mathrm{C}$ and $220^{\circ} \mathrm{C}$ (Table 4). This is in agreement with previous report that showed an increase in oven temperature decreases the lightness of biscuit, independent of heat transfer mode of oven temperature to the product $\left(>190^{\circ} \mathrm{C}\right)$ [27]. Further heating time, such as 9 and 12 min at $200^{\circ} \mathrm{C}$ and $220^{\circ} \mathrm{C}$ led to almost charring of the biscuit surface.

The color characteristics of the baked products showed that increasing baking temperature and time lowered the lightness value (L) but increased the redness (a) and yellowness (b) (data not shown). Table 4 shows a gradual increase in overall colour difference $\left(\Delta \mathrm{E}_{\mathrm{ab}}\right)$ values with increase in baking temperature and time in encapsulated as well as unencapsulated biscuits. This indicates a gradual transformation of biscuit colour from lighter to much deeper yellow and red colour and finally into much darker product.

\subsection{Change in Texture Profiles}

Biscuit baked at $180^{\circ} \mathrm{C}$ for $5 \mathrm{~min}$ required the lowest force to break the biscuits (Table 4). The force increased with increase in baking time. Lower hardness in low temperature/time baked biscuits indicates less brittle (but crunchy) biscuits with greater internal cohesiveness and springiness [28]. It is also likely that the biscuits at this stage were still not fully cooked and had a relatively softer texture. With increase in time and temperature, further development of gluten matrix as well as starch gelatinization and retrogradation occurs that might entrap

Table 4. Measurement of texture, moisture and change in colour characteristics of biscuits baked at different temperatures and times.

\begin{tabular}{|c|c|c|c|c|}
\hline \multirow{2}{*}{ Physical properties } & \multirow{2}{*}{ Baking temperature $\left({ }^{\circ} \mathrm{C}\right)$} & \multicolumn{3}{|c|}{ Baking time (min) } \\
\hline & & 5 & 9 & 12 \\
\hline \multirow{3}{*}{ Texture $(\mathrm{N})^{1,3}$} & 180 & $47.9 \pm 10.1$ & $81.2 \pm 5.0$ & $86.9 \pm 5.0$ \\
\hline & 200 & $56.1 \pm 12.0$ & $74.4 \pm 5.4$ & $65.1 \pm 9.6$ \\
\hline & 220 & $86.6 \pm 5.7$ & $74.9 \pm 4.4$ & $62.9 \pm 7.3$ \\
\hline \multirow{3}{*}{ Moisture $(\%)^{2}$} & 180 & $7.4 \pm 0.4$ & $4.0 \pm 0.4$ & $3.1 \pm 0.3$ \\
\hline & 200 & $6.5 \pm 0.3$ & $3.7 \pm 0.2$ & $2.1 \pm 0.3$ \\
\hline & 220 & $4.5 \pm 0.3$ & $2.1 \pm 0.3$ & $1.4 \pm 0.2$ \\
\hline \multirow{3}{*}{ Change in colour $\left(\Delta E_{a b}^{*}\right)^{1}$} & 180 & $42.0 \pm 0.2$ & $47.7 \pm 0.3$ & $50.7 \pm 0.2$ \\
\hline & 200 & $47.9 \pm 0.3$ & $52.2 \pm 0.4$ & $51.4 \pm 0.4$ \\
\hline & 220 & $51.1 \pm 0.4$ & $59.4 \pm 0.5$ & $58.7 \pm 0.4$ \\
\hline
\end{tabular}

$\overline{{ }^{1} \text { Values represent mean of six replicates } \pm \text { standard deviation; }{ }^{2} \text { Values represent mean of triplicates } \pm \text { standard deviation; }{ }^{3} \text { Maximum force (Newton) needed to }}$ break biscuits. 
moisture in their matrix. Besides, moisture release from the surface might have hampered as the crust is sealed due to plasticization of proteins and starch. This might lead to a more hard, brittle and cohesive mass that needs greater force to break the biscuits. It was difficult to compare the force needed to break biscuits baked at 200 and $220^{\circ} \mathrm{C}$ as the biscuit surface (interior in some cases) started to carbonize due to high temperature and baking time. For example, for biscuits with encapsulated 5$\mathrm{CH}_{3} \mathrm{THF}$ baked at $220^{\circ} \mathrm{C}$, the breaking force started to drop with increasing baking time (Table 4). It is likely that the biscuit become hard and brittle that poses less resistance to breaking force. Results showed a distinguishable variation in measurable hardness of biscuits. Ahmad and colleagues have reported that the texture of biscuits vary within the same biscuit due to non-uniform moisture distribution, particularly in conventional oven [29].

\subsection{Change in Moisture Content}

As expected the moisture content of the biscuits decreased with increase in baking temperature and time (Table 4). The initial moisture content of the dough containing encapsulated $5-\mathrm{CH}_{3} \mathrm{THF}$ was $16 \%$ (dry basis) which decreased to $7.8 \%, 6.3 \%$ and $4.6 \%$ when baked for 5 minutes at $180^{\circ} \mathrm{C}, 200^{\circ} \mathrm{C}$ and $220^{\circ} \mathrm{C}$, respectively. These values further decreased to $2.7 \%, 1.7 \%$ and $1.4 \%$ when baked for $12 \mathrm{~min}$ at $180^{\circ} \mathrm{C}, 200^{\circ} \mathrm{C}$ and $220^{\circ} \mathrm{C}$, respectively. The moisture loss trend in biscuits with unencaspsulated $5-\mathrm{CH}_{3} \mathrm{THF}$ was similar to encapsulated ones, therefore, not reported. Moisture loss during the first 5 min caused more than half of the initial moisture in the dough. As expected, the moisture loss was too low and too quick while drying at $220^{\circ} \mathrm{C}$ which leads to scorching and slight charring of the biscuit surface. Low moisture content in biscuits resulted in brittleness, as shown by breakdown at lower peak force (Table 4). It has been widely reported that non-uniform distribution of moisture in the biscuit during baking and drying affect the texture formation and hardness [29].

\section{Conclusion}

Microencapsulation is a technique that provides protection to highly susceptible micronutrients including 5$\mathrm{CH}_{3}$ THF. Use of pectin and alginate solution as encapsulating material showed increased pectin in the mixture resulting in higher loading efficiency of $5-\mathrm{CH}_{3} \mathrm{THF}$. The inclusion of encapsulated and unencapsulated 5- $\mathrm{CH}_{3} \mathrm{THF}$ in the biscuit formulation and subsequent baking at various temperatures and times resulted in retention of 5$\mathrm{CH}_{3} \mathrm{THF}$ from $19.1 \%$ to $1.7 \%$. It seems intense heating that caused "over baking" of the biscuit likely to be re- sponsible for the loss of the vitamin. Physical analysis showed darker colour, harder texture and lower moisture for biscuits baked at higher test temperatures.

\section{Acknowledgements}

Early Career Research Grant from the Office of Research and Postgraduate Studies (ORPS), The University of Queensland, Brisbane, Australia, is gratefully acknowledged.

\section{REFERENCES}

[1] J. Selhub, "Folate, Vitamin B12 and Vitamin B6 and One Carbon Metabolism," Journal of Nutrition, Health and Aging, Vol. 6, No. 1, 2002, pp. 39-42.

[2] M. Lucock and Z. Yates, "Folic Acid Fortification: A Double-Edged Sword," Current Opinion in Clinical Nutrition and Metabolic Care, Vol. 12, No. 6, 2009, pp. 555-564. doi:10.1097/MCO.0b013e32833192bc

[3] S. Abeywardana, C. Bower, J. Halliday, J. A. Chan and E. A. Sullivan, "Prevalence of Neural Tube Defects in Australia Prior to Mandatory Fortification of Bread-Making Flour with Folic Acid," Australian and New Zealand Journal of Public Health, Vol. 34, No. 4, 2010, pp. 351355. doi:10.1111/j.1753-6405.2010.00565.x

[4] A. Chan, P. van Essen, H. Scott, E. A. Haan, L. Sage, J. Scott, T. K. Gill and A. T. Nguyen, "Folate Awareness and the Prevalence of Neural Tube Defects in South Australia 1966-2007," Medical Journal of Australia, Vol. 189, No. 10, 2008, pp. 566-569.

[5] National Health and Medical Research Council, "Folate Fortification: Report of the Expert Panel on Folate Fortification," Australian Government Publishing Service, Canberra, 1995.

[6] A. J. A. Wright, P. M. Finglas and S. Southon, "Proposed Mandatory Fortification of the UK Diets with Folic Acid: Have Potential Risks Been Underestimated?" Trends in Food Science and Technology, Vol. 12, No. 9, 2001, pp. 313-321. doi:10.1016/S0924-2244(01)00099-1,

[7] K. Pentieva, H. McNulty, R. Reichert, M. Ward, J. J. Strain, D. J. McKilliop, J. M. McPartlin, E. Connolly, A. Molloy, K. Kramer and J. M. Scott, "The Short Term Bioavailabilities of [6S]-5-Methyltetrahydrofolic Acid and Folic Acid Are Equivalent in Men," Journal of Nutrition, Vol. 134, No. 3, 2004, pp. 580-585.

[8] Food Standards Australia and New Zealand, "Fortification of Bread with Folic Acid," Report by Access Economics Pty Ltd. for FSANZ, FSANZ, Canberra, 2006.

[9] A. K. Shrestha, J. Arcot and S. Yuliani, "Susceptibility of 5-Methyltetrahydrofolate to Heat and Microencapsulation to Enhance Its Stability during Extrusion Processing," Food Chemistry, Vol. 130, No. 2, 2011, pp. 291-298. doi:10.1016/j.foodchem.2011.07.040

[10] S. Kariluoto, L. Vahteristo, H. Salovaara, K. Katina, K. Liukkonen and V. Piirone, "Effect of Baking Method and Fermentation on Folate Content of Rye and Wheat Breads," 
Cereal Chemistry, Vol. 81, No. 1, 2004, pp. 134-139.

doi:10.1094/CCHEM.2004.81.1.134

[11] E. Gujska and P. Majewska, "Effect of Baking Process on Added Folic Acid and Endogenous Folates Stability in Wheat and Rye Breads," Plant Foods Human Nutrition, Vol. 60, No. 2, 2005, pp. 37-42.

[12] S. Tomiuk, Y. Liu, T. J. Green, M. J. King, P. M. Finglas and D. D. Kitts, "Studies on the Retention of Microencapsulated L-5-Methyltetrahydrofolic Acid in Baked Bread Using Skim Milk Powder," Food Chemistry, Vol. 133, No. 2, 2012, pp. 249-255.

[13] H. Madziva, K. Kailasapathy and M. Phillips, "Alginatepectin Microcapsules as a Potential for Folic Acid Delivery in Foods," Journal of Microencapsulation, Vol. 23, No. 4, 2005, pp. 343-351.

[14] S. Jisha, G. Padmaja and M. S. Sajeev, "Nutritional and Textural Studies on Dietary Fiber Enriched Muffins and Biscuits from Cassava-Based Composite Flours," Food Quality, Vol. 33, No. S1, 2010, pp. 79-99.

[15] A. I. Ihkeronye and P. O. Ngoddy, "Integrated Food Science \& Technology for the Tropics," McMillan, London, 1985, pp. 165-193.

[16] AOAC International, "Official Methods of Analysis of AOAC," AOAC International, Gaithersburg, 1995.

[17] J. Arcot, A. K. Shrestha and U. Gusanov, "Enzyme Protein Binding Assay for Determining Folic Acid in Fortified Cereal Foods and Stability of Folic Acid under Different Extraction Conditions," Food Control, Vol. 13, 2001, pp. 245-252.

[18] A. K. Shrestha, J. Arcot and J. L. Paterson, "Folate Assay of Foods by Traditional and Tri-Enzyme Treatments Using Cryoprotected Lactobacillus casei," Food Chemistry, Vol. 71, No. 4, 2000, pp. 545-552.

[19] A. K. Shrestha, J. Arcot and J. L. Paterson, "Fortification of Rice with Folic Acid Using Edible Polymers," Food Research International, Vol. 36, No. 9, 2003, pp. 921-
928.

[20] P. Walkenstrom, S. Kidman, A.-M. Hermansson, P. B. Rasmussen and L. Hoegh, "Microstructure and Rheological Behaviour of Alginate/Pectin Mixed Gels," Food Hydrocolloids, Vol. 17, No. 5, 2003, pp. 593-603.

[21] J. D. Dziezak, "Microencapsulation and Encapsulation Ingredients," Food Technology, Vol. 2, No. 4, 1988, pp. 136-151.

[22] T. S. Chen and R. G. Cooper, "Thermal Destruction of Folacin," Journal of Food Science, Vol. 44, No. 33, 1979 , pp. 713-716.

[23] H. Wallin, "Calcium L-5-Methyltetrahydrofolate (L-5$\mathrm{CH}_{3}$ THF-Ca), Chemical and Technical Assessment 65th JECFA," Joint FAO/WHO Expert Committee on Food Additives, Rome.

[24] V. Ohrvik, H. Ohrvik, J. Tallkvist and C. Witthoft, "Folates in Bread: Retention during Bread-Making and in Vitro Bioaccessibility," European Journal of Nutrition, Vol. 49, No. 6, 2010, pp. 365-372.

[25] Biodar, "Unpublished Study Report of Biodar Ltd.," Yavne, 2000.

[26] P. J. Fellows, "Food Processing Technology Principles and Practice," Woodhead Publishing Ltd., Cambridge, 2009.

[27] E. Lara, P. Cortés, V. Briones and M. Perez, "Structural and Physical Modifications of Corn Biscuits during Baking Process," LWT-Food Science and Technology, Vol. 44, No. 3, 2011, pp. 622-630.

[28] A. S. Szczesniak, "Classification of Textural Characteristics," Journal of Food Science, Vol. 28, 1963, pp. 385389.

[29] S. S. Ahmad, M. T. Morgan and M. R. Okos, "Effects of Microwave on the Drying, Checking and Mechanical Strength of Baked Biscuits," Journal of Food Engineering, Vol. 50, No. 2, 2001, pp. 63-75. 